Article

\title{
The Challenge of Diffusion in Forest Plans: A Methodological Proposal and Case Study
}

\author{
Xabier Bruña-García * (iD) and Manuel F. Marey-Pérez ${ }^{(D)}$ \\ Research group of Projects \& Planification/IDEGA, University of Santiago de Compostela, \\ 27002 Lugo, Spain; manuel.marey@usc.es \\ * Correspondence: ringojbg@yahoo.es; Tel.: +34-982-823-247
}

Received: 22 March 2018; Accepted: 30 April 2018; Published: 2 May 2018

\begin{abstract}
Society's participation in decisions regarding land planning and management is essential for reaching viable and long-lasting solutions. The success of forest plans depends on the involvement of different stakeholders. In turn, stakeholder involvement depends on the representativity achieved in public participation in the development of the plan. The first stage, diffusion, is the key element in the process. This paper describes a methodology for the diffusion stage that obtains six times more participants than a similar process. Its aim is to achieve stakeholder representativity in the forestry sector in forest planning at a subregional level. The methodology is validated and applied in a municipality of Galicia, north-west Spain. It is evaluated in terms of efficiency considering the effort in each stage and the results achieved.
\end{abstract}

Keywords: participatory process; forest governance; diffusion; social forestry; stakeholder analysis

\section{Introduction}

Land planning is a complex issue [1,2], an active process that requires careful thought about the future and involves the coordination of all relevant activities for achieving specified goals and objectives [2]. Planning is an integral component of forest management. It is about determining and expressing the goals and objectives of the government, rural communities or companies, and deciding the targets and steps that should be taken to achieve these objectives [2]. Planning is not necessarily a complicated process, but it requires clear objectives. It requires imagination and a willingness to consider all points of view relevant to a given situation. The planning process should lead to a balanced outlook from which proposals for effective management can be written [3].

There is no single universal public participation model, but different ones depending on each particular case [4]. The studies examined in Table 1 propose different solutions to the issue of the number of stakeholders involved. The average is of four categories-generic groups of stakeholders-14 groups and 54 participants. There is a higher variability in the number of participants than in the number of stakeholders. It is interesting to identify the elements used to classify and identify stakeholders in the different cases (Table 1) regardless of the place where they are implemented.

The inclusion of people's opinions about the technical aspects of forest resources and their management has sparked scientific debate [5-11]. In a modern sense, public participation in the devising of forest plans is, preferably, voluntary [12,13]. Within public participation processes, people, individually or in organized groups, can exchange information, express opinions and articulate interests with the aim of influencing the final result of decision-making [12-14]. It is both an opportunity and a need for society today, as it is a useful tool to avoid conflicts, share information and encourage good relations with the planning team [15-19]. Public participation contributes to democratization through the reinforcement of transparency in decision-making: it increases the plurality of aims, 
encourages mutual learning, and increases the awareness of collective responsibility for natural resource-management questions [20-23].

There are several levels of participation within decision-making processes in forest-resource planning. They range from passive participation, where stakeholders are informed about the decisions made by others, to interactive participation, which involves joint decision-making and shared responsibility [20,24-26].

A thorough analysis and classification of stakeholders is essential in the beginning of a public participation process. If important stakeholders are left out, key issues may be ignored and the assessment of the situation will be incomplete $[9,27]$. A second risk of leaving out key stakeholders is that those key stakeholders will use their exclusion to attack the legitimacy of the process as a whole [28] Multifunctional and modern management requires coordination and agreement between diverging and contradictory stakeholders. Therefore, mutual communication and participation of all identified stakeholders is necessary [13].

The process of public participation is divided into three consecutive stages: diffusion, debate and proposals. There are many references in the literature regarding the last two stages, debate and proposal selection, especially to the use of multiple criteria decision analysis (MCDA) tools, described by Hwang and Yoon [29], and used by authors such as: Pykäläinen et al. [30], Kangas and Kangas [31], Ananda and Herath [32,33], Maness and Farrell [34], Laukanen et al. [35], Sheppard and Meitner [36], Hiltunen et al. [37], Ananda and Herath [38], and Hiltunen et al. [19].

There is an international agreement that participation is a basic principle in forest-resource plans [39,40], but there are no guidelines regarding who should participate [39,41]. Grimble and Wellard [42], Banville et al. [43] and Nordström et al. [27] define the stakeholder as "someone who is affected by or can affect the situation in some way; that is, the stakeholders have vested interests in the decision problem". Therefore, stakeholders are the people and the institutions that depend on or obtain benefits from forest resources or those that decide, control or regulate access to those resources [36]. According to this, stakeholders may or may not be formally organized and individual or collective. For us, participants are the people taking part in the participation process who are members of at least one stakeholder. Sheppard and Meitner [36] propose the classification of participants according to criteria related to property rights, the history of planning processes, reputation, influence and importance. Gong et al. [44] consider property rights, social capital and contractual rules as key elements. Nordström et al. [27] consider that the aims of stakeholder analysis stem from the identification of the most relevant stakeholders and the determination of the scope of their participation. On the one hand, Tikkanen et al. [45] divide stakeholders in the forestry sector on a regional level into three main groups of cooperation: private forestry-oriented, environment and nature-oriented, and background (the background group is formed by those participants with a mixed orientation between economic and environmental criteria). This clear division may lead the participants to defend their own interests instead of truly collaborating with others. On the other hand, Leskinen [7] observed that each group of actors has similar aims in relation with forestry programs in all the regions studied, regardless of the characteristics of the forests or the socioeconomic structure of the region. This confirms the existence of general categories of stakeholders [18]. Recently, Paletto et al. [46] propose a non-subjective method to identify and classify stakeholders by social network analysis (SNA).

O'Neill [47] and Elsasser [39] determined representativity as the main issue in any public participation process. In this sense, a broad representation of various interests in the planing process is essential (McCool and Gutrie [48]. Sheppard and Meitner [36] present several criteria for an effective participatory process and the first is a broad representation of stakeholders. For Buchy and Hoverman [28], representativity is one of the four principles of good practices in public participation from the perspective of the inclusión of all those who would like to participate and to facilitate their participation. Since there is no clear definition, from the perspective of public participation we understand representativity as a balanced and reliable participation of the people and organization 
with interests in the territory to be planned. Reliable participation is reached when stakeholders and territories are minimally represented in the process.

Examples of different methodologies applied to public participation processes are those by Sheppard and Meitner [36], Martins and Borges [49], Díaz-Balteiro and Romero [1], Food and Agriculture Organization (FAO) [50], Kangas et al. [21], and Paletto et al. [46]. All these works have in common the fact that the process starts with a diffusion stage and includes an appeal for the participation of the population. Authors such as FAO [50], Beierle and Cayford [51], Higgs et al. [25] pose the key questions of who must participate and when. The process has to guarantee representativity [52], a balanced composition of the participating groups [24,53], and the integration of public participation within the technical process for the development of the plan. "The development of rural landscapes is a major challenge for planning and puts a great degree of responsibility in the hands of decision-makers. But successful planning depends on the acceptance of the public and thus interests of stakeholders play a crucial role" [54]. Diffusion is key in the participative process since it arises from people's interest in taking part in the process from the beginning. The principles for the success of the public participation process stated by Nordström et al. [27] depend on this stage.

Public participation in forest-plan design has been a source of scientific debate [55]. Our contribution in this paper is to answer questions such as who can and must participate in these processes; how many people and how many members of each group can and must participate; how participation should take place; and how much is the cost associated with this process is. To achieve this goal, we propose a methodology of diffusion as a first stage of the public participation process. The methodology is validated in a tactical forest plan in the forest district of Fonsagrada-Os Ancares in the autonomous community of Galicia, north-west Spain.

Table 1. Characteristics of participants in different public participation processes.

\begin{tabular}{|c|c|c|c|c|c|}
\hline Case & Surface & Number of Categories & Stakeholders & Participants & Reference \\
\hline $\begin{array}{l}\text { Ostrobothnia region of the Coastal } \\
\text { Forestry Centre }\end{array}$ & $\begin{array}{l}528,000 \text { ha } \\
\text { forest }\end{array}$ & - & 5 & 20 & [55] \\
\hline Arrow Forest District & $40,000 \mathrm{~km}^{2}$ & - & 9 & 47 & [36] \\
\hline $\begin{array}{l}\text { Finnish National } \\
\text { Forest Programme }\end{array}$ & - & - & 12 & 74 & [56] \\
\hline Portuguese Chamusca County & - & 4 & 11 & $\begin{array}{l}32 \text { out of } \\
22 \text { entities }\end{array}$ & [57] \\
\hline $\begin{array}{l}\text { Comunità Montana Collina } \\
\text { Materana }\end{array}$ & $\begin{array}{c}60,784 \text { ha } \\
(19.8 \% \text { forest })\end{array}$ & 2 & 9 & 63 & {$[58,59]$} \\
\hline Västerbotten in northern Sweden & 8637 ha & 4 & 33 & - & [27] \\
\hline Distretto Arci-Grighine & $\begin{array}{c}55,183 \text { ha } \\
\text { (43.20\% forest) }\end{array}$ & 2 & 12 & 124 & {$[58,59]$} \\
\hline $\begin{array}{l}\text { NRP in Eastern and Western } \\
\text { Lapland, Finland. }\end{array}$ & $\begin{array}{l}1.1 \text { million ha } \\
\text { forest }\end{array}$ & - & 8 & 16 & [19] \\
\hline $\begin{array}{l}\text { Regional Forest Programmes } \\
\text { in Finland }\end{array}$ & - & 8 & 40 & - & [21] \\
\hline Average & - & 4 & 14 & 54 & - \\
\hline Variance & & 6 & 150 & 1419 & \\
\hline
\end{tabular}

\section{Material and Methods}

\subsection{The Case Study Area}

In the case of Galicia (north-west Spain) (Figure 1), the forest area of 2,060,453 ha accounts for $69 \%$ of the region. It has a high potential for forest productivity [60]. In the year 2010, this reached $6,868,500 \mathrm{~m}^{3}$, which represents $50 \%$ of Spanish timber production and about $4.5 \%$ of that in the European Union [60]. Galicia is characterized by the presence of small forest owners [61,62], agricultural exploitation [63-65], and a mosaic of cropped and livestock-farmed and forested land [66]. For 40 years there has been an increase in the process of afforestation in different agricultural areas and in the abandonment of rural activities [67], together with a sharp decrease in population in rural areas [67]. 
Forests have been managed primarily by individual private owners. Over $96.6 \%$ of forest lands in Galicia are privately held and about $63.7 \%$ of forest land is managed by 672,618 individual private owners, with an average forest land of 1.8 ha per owner [62]. Farmers comprise $29.8 \%$ of these owners and $19.5 \%$ of them own productive and commercial woodlands [62]. The remaining private forests correspond to communal forests, named Montes Veciñais en Man Común (MVMC), a communal form of private land tenure. There are 2878 MVMC units, with an average area of 230 ha [68]. Woodlands account for $15.1 \%$ of the MVMC land and $81.5 \%$ of the individual private area [68]. Thus, in contrast with the situation reported for forests owned by individual private owners, Galician communal forests have a huge potential for forest exploitation because of their large average size. Moreover, Galician communal forests have considerable economic power and rely on integrated and professional management.

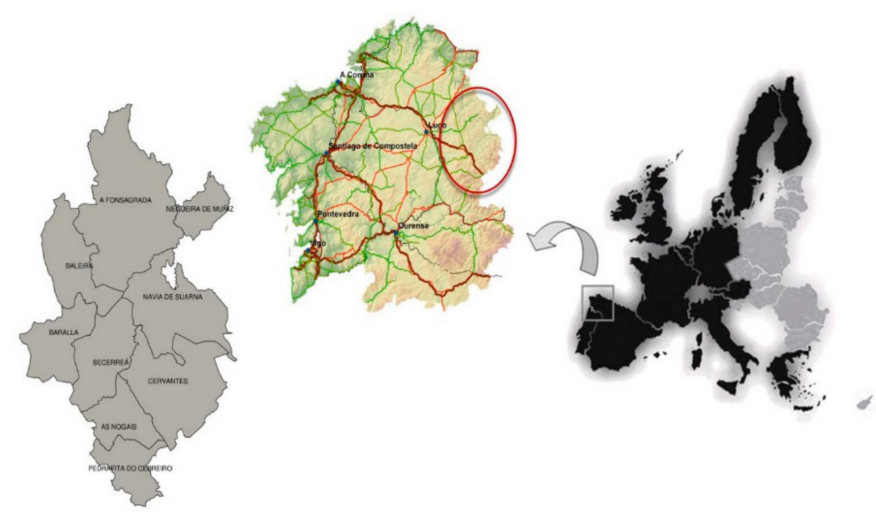

Figure 1. Location of the Fonsagrada-Ancares forest district.

The study area was the Fonsagrada-Ancares forest district, made up of nine municipalities in the eastern part of the province of Lugo (Figure 1) (geographical coordinates: $43^{\circ} 18^{\prime}, 7^{\circ} 0^{\prime}$ North, $42^{\circ} 36^{\prime}$, $7^{\circ} 3^{\prime}$ South, $42^{\circ} 54^{\prime} \mathrm{N}, 7^{\circ} 19^{\prime}$ West and $42^{\circ} 51^{\prime}, 6^{\circ} 44^{\prime}$ East). Forested land covers a total area of 87,828 ha. $63.6 \%$. It is rural area of $1728 \mathrm{~km}^{2}$ with a population of 19,111 people [69] and a population density of 11.06 people $/ \mathrm{km}^{2}$ that is unevenly spread and far below the European average of 116 people $/ \mathrm{km}^{2}$ [70].

The area is becoming increasingly depopulated due to the lack of services and economic opportunities to replace agriculture and cattle breeding. The population pyramid, in Figure 2, shows the regressive trend characteristic of ageing populations. As a result of the loss of population, the physiographic characteristics and suitable productive capacity, the forest surface has increased to up to $65 \%$ of the total surface today [67].

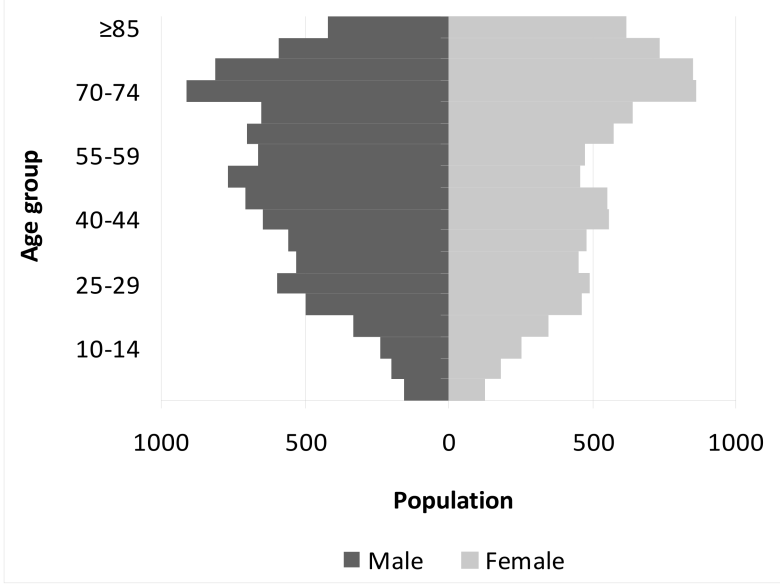

Figure 2. Population pyramid of the Fonsagrada-Os Ancares forest district. 


\subsection{Methods}

The methodology, shown in Figure 3, has been developed considering our experience in several participation processes using different methodologies. We know the importance of incorporating a sufficient number of participants from the first stages of the plan onwards. We also know how difficult it is to incorporate new participants once the process has begun. The proposal consists of four stages that have to be developed in a short period of time and in a coordinated form to solve the problems that may arise. We explain each stage in the following sections.

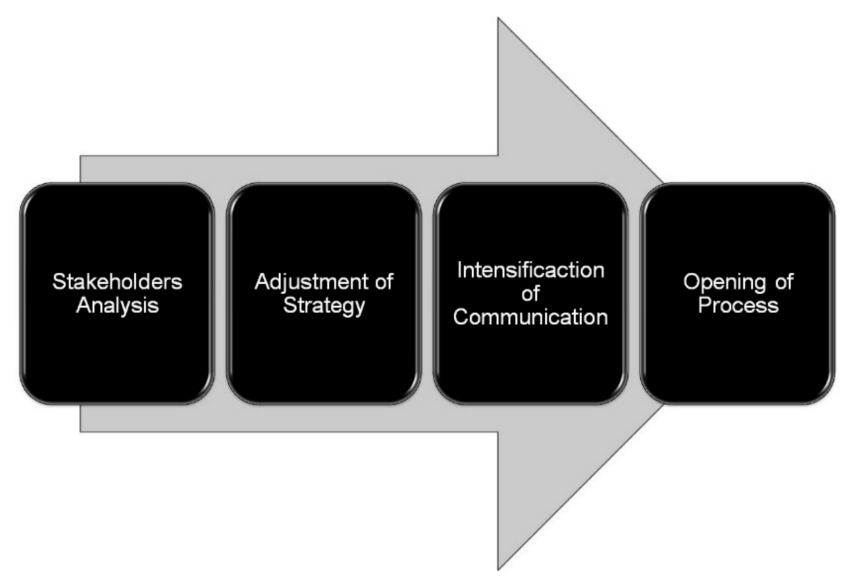

Figure 3. Stages in the diffusion phase.

\subsubsection{Stakeholder Analysis}

First, the agents involved must be characterized, considering current property rights, planning process history in the area, and previous knowledge about the social framework. Then, the following classification criteria are established: (1) importance of the different stakeholders; (2) experience in participation; (3) necessity of sectorial and territorial representation.

We propose three categories to answer the basic questions about a forest plot: (a) who owns it; (b) who can use it; and (c) who regulates it, as shown in Figure 4. The stakeholders in the area are selected from within these categories. The process of stakeholder selection makes it possible to carry out the diffusion stage directed towards the most representative, who are those directly affected by the decisions of the plan. A minimum number of participants, distributed by sectors and by territory, must be initially determined for a correct representativity in the participative process. This percentage is established as a balance between the statistical and technical rigor of the work and the financial resources and staff availability.

We drew up a census of potential participants in the process distributed by territory and stakeholder. Then, we established a first objective so that a minimum percentage of the population attended the meetings (territory). After that, we established further minimum percentages for the involvement in the process of each stakeholder. This two-fold process aims at territorial and sectorial representativity.

\subsubsection{Adjustment of Strategy}

Once the stakeholders are identified, diffusion must be carried out with two types of strategy: generic and specific.

(i) Generic: a simple message is broadcast by different media so that it reaches all stakeholders. Its aims are (1) to announce the beginning of the public participation process; and (2) to call for informative meetings on a local level.

(ii) Specific: this strategy is adapted to each stakeholder. It consists of three parts: (1) identification of leaders and representatives; (2) creation of a specific message for each group coordinated with the 
general message; (3) setting up of a system of communication that guarantees that the leaders receive the message. Figure 5 shows the first two stages of the specific strategies. The letters $(A, B, C, D, E \ldots)$ represent the different stakeholders. The size of the figures represents the numerical weight of each stakeholder. Their superposition represents the existence of a range of individuals that belong to two or more stakeholders, since excluding criteria are not considered. The letters MG stand for general message and M1, M2, M3 ... represent specific messages.

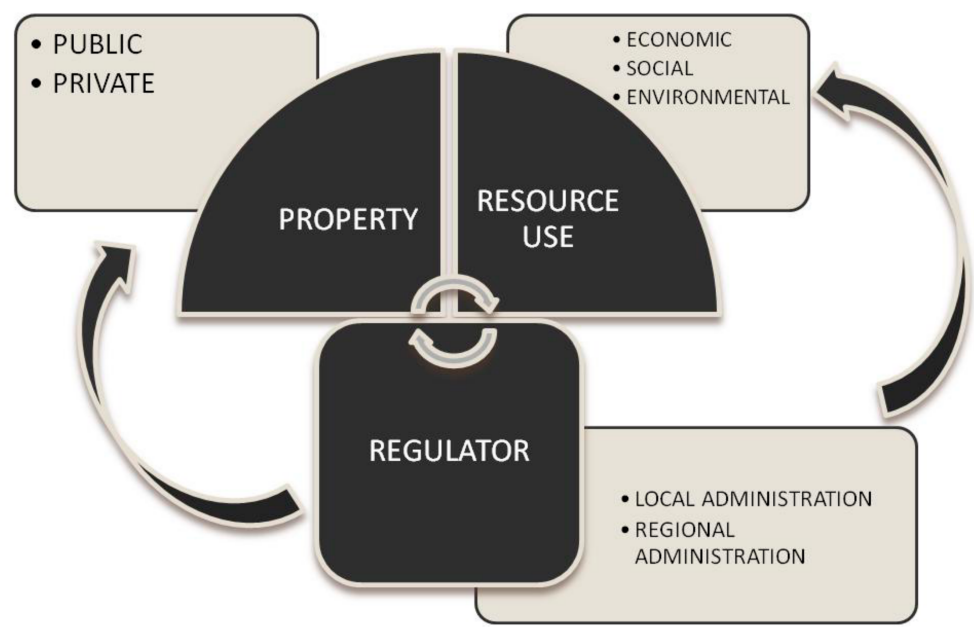

Figure 4. Distribution categories of stakeholders.

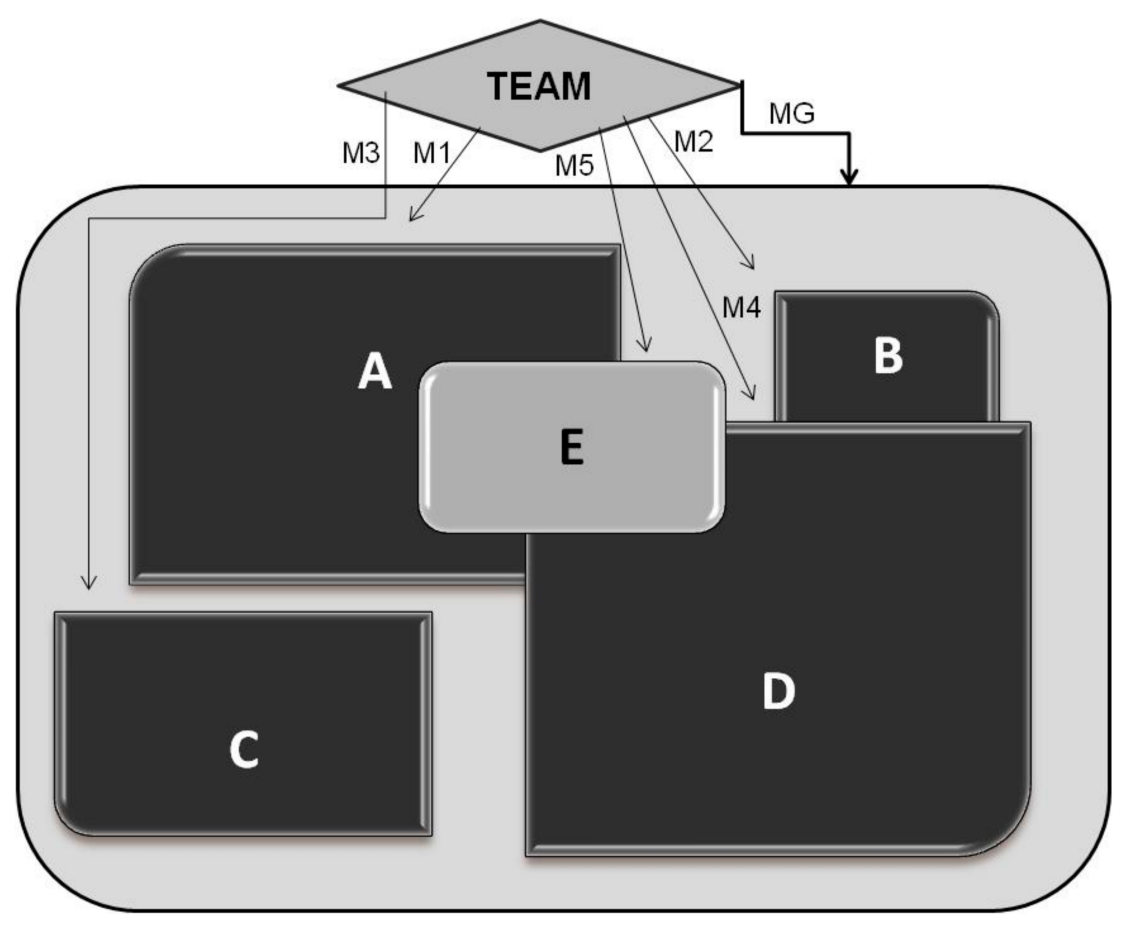

Figure 5. Specific strategy in a public participation process.

\subsubsection{Intensification of Communication}

Results of the incorporation of participants in the process and their distribution by groups are to be analyzed and compared with the proposed aims. In case the aims are not fulfilled totally or partially, both the message and the method will be revised. This revision is essential to improve the quality of the process and to take corrective measures for its improvement [71]. 


\subsubsection{Opening of Process}

Once the presence and the representation of all relevant and representative stakeholders of the area has been guaranteed, the process is open to all those interested to ensure an open and democratic process. There are some proposals for this stage that include the use of the internet in forest-resource planning and teledemocracy [16]. The use of new technologies provides the process with transparency and equity [25].

This can alter its development, but it is necessary to guarantee a real public participation process [72], where all those affected have the chance of participating.

\section{Results}

\subsection{Stakeholder Analysis}

Twelve stakeholders have been identified in the process within the three main categories established in the methodology. Both the number of categories (3) and the number of groups (12) are similar to those published by other authors (see Table 1). Within the category of property, we included individual and collective owners, known as comuneros, as they are the types of property present in the area of validation [63]. We included the public administrations that regulate land-use and forest activity within the category of regulators: local administration (municipalities) and forest administration (dependent on the regional administration). We included eight stakeholders that encompass the direct and indirect uses of forest resources within the category of resource users on the territory: farmers, cattle breeders, beekeepers, hunters, companies, owner associations and non-profit organizations (represented by letters A, B, C, D, E in Figure 5). The identification of these stakeholders was carried out with a directed process that considers the social characteristics of the area and the effective use of the forest resources. Maintaining the objective to achieve maximum representativity, we established a guided model based on the social map of the territory, drawn up in the technical part of the district's forestry plan and studies, and previous experiences of the drafting team. Paletto et al. [46], for the Forest Landscape Management Plan (FLMP) in Italy, use social network analysis (SNA) to classify them into three categories: key, primary and secondary stakeholders, a figure equivalent to that of this work.

In our study, the inhabitants are the people who live in the area that is subject to planning and the potential participants are the people or groups that are members of the stakeholders that may or may not live in the area that is subject to planning. The initial population is the whole of the population whom the public participation process is aimed at. It is the sum of all potential participants. We analysed the representativity of the potential participants in each group on this population (Table 2).

Table 2. Initial population by category and stakeholders.

\begin{tabular}{|c|c|c|c|c|c|}
\hline Category & Stakeholder & Subtotal & Total & $\%$ Subtotal & $\%$ Total \\
\hline \multirow{2}{*}{ Property } & Individual forest owners ${ }^{1}$ & 9776 & \multirow{2}{*}{18,569} & 42.64 & \multirow{2}{*}{81} \\
\hline & Collective forest owners ${ }^{4}$ & 8793 & & 38.35 & \\
\hline \multirow{2}{*}{ Regulator } & Local administration $^{1}$ & 9 & \multirow{2}{*}{241} & 0.04 & \multirow{2}{*}{1.05} \\
\hline & Forest administration ${ }^{1}$ & 232 & & 1.01 & \\
\hline \multirow{7}{*}{ Resource user } & Farmers and stockbreeders ${ }^{2}$ & 1983 & \multirow{7}{*}{4116} & 8.65 & \multirow{7}{*}{17.95} \\
\hline & Hunters $^{2}$ & 1363 & & 5.95 & \\
\hline & Beekeeper $^{2}$ & 439 & & 1.91 & \\
\hline & Local forest company ${ }^{3}$ & 53 & & 0.23 & \\
\hline & Other related companies ${ }^{3}$ & 110 & & 0.48 & \\
\hline & Forest owners' associations ${ }^{1}$ & 3 & & 0.01 & \\
\hline & $\begin{array}{l}\text { Ecological groups }{ }^{1} \\
\text { Non-profit organizations }{ }^{1}\end{array}$ & 165 & & 0.72 & \\
\hline TOTAL & & 22,926 & 22,926 & $100 \%$ & $100 \%$ \\
\hline
\end{tabular}

${ }^{1}$ Forest Resource Management Plan; ${ }^{2}$ Consellería de Medio Rural, Xunta de Galicia; ${ }^{3}$ Database SABI. (Bureau Van Dijk); ${ }^{4}$ INE (National Statistics Institute) and IGE (Galician Statistics Institute). 
We established a percentage of the census ( $1 \%$ in both cases) for the first objective, who attended the meeting of each municipality, and for the second, a percentage of participants of each stakeholder in the participatory process. Tables $3-5$ show the results obtained. We chose this limit after considering the diagnosis of the current state of the population, a lack of participatory culture, demographic and physiographic characteristics, and the distribution of population settings. Once we set the goal of participation, the diffusion process started.

Table 3 shows the results obtained for the real distribution and for the theoretical distribution, which was initially our aim.

Table 3. Initial real and theoretical distribution of representativity in the participation process.

\begin{tabular}{ccc}
\hline Groups & \multicolumn{2}{c}{ Representatives } \\
\cline { 2 - 3 } & Real & Theoretical \\
\hline Individual forest owners & 135 & 98 \\
Collective forest owners & 81 & 88 \\
Farmers and stockbreeders & 44 & 20 \\
Hunters & 8 & 14 \\
Beekeeper & 1 & 1 \\
Local forest company & 10 & 4 \\
Other related companies & 1 & 1 \\
Local administration & 1 & 0 \\
Forest administration & 8 & 2 \\
Forest owners associations & 1 & 0 \\
Ecological groups & 6 & 0 \\
Non-profit organizations & 7 & 0 \\
Total & 303 & 229 \\
\hline
\end{tabular}

Table 4. Attendance at information meetings.

\begin{tabular}{|c|c|c|c|c|c|}
\hline Information Meeting & $\begin{array}{c}\text { Number of } \\
\text { People Present }\end{array}$ & Inhabitants & $\%$ Municipality & $\begin{array}{c}\text { Initial } \\
\text { Population }\end{array}$ & $\begin{array}{c}\% \text { Initial } \\
\text { Population }\end{array}$ \\
\hline Baleira & 44 & 1658 & 2.65 & 2230 & 1.97 \\
\hline Baralla & 48 & 3034 & 1.58 & 2546 & 1.89 \\
\hline Becerreá & 72 & 3264 & 2.21 & 3406 & 2.11 \\
\hline Cervantes & 71 & 1844 & 3.85 & 2837 & 2.5 \\
\hline A Fonsagrada & 107 & 4748 & 2.25 & 6317 & 1.69 \\
\hline Navia de Suarna & 57 & 1552 & 3.67 & 1866 & 3.05 \\
\hline Negueira de Muñiz & 27 & 222 & 12.16 & 532 & 5.08 \\
\hline As Nogais & 16 & 1421 & 1.13 & 1552 & 1.03 \\
\hline Pedrafita do Cebreiro & 11 & 1368 & 0.80 & 1240 & 0.89 \\
\hline TOTAL & 453 & 19,111 & 2.37 & 22,526 & 2.01 \\
\hline
\end{tabular}

Table 5. Attendance at information meetings in the intensification stage.

\begin{tabular}{cccccc}
\hline $\begin{array}{c}\text { Information } \\
\text { Meeting }\end{array}$ & $\begin{array}{c}\text { Number of } \\
\text { People Present }\end{array}$ & Inhabitants & \% Municipality & $\begin{array}{c}\text { Initial } \\
\text { Population }\end{array}$ & $\begin{array}{c}\text { \% Initial } \\
\text { Population }\end{array}$ \\
\hline As Nogais & 24 & 1421 & 1.69 & 1552 & 1.54 \\
Pedrafita do Cebreiro & 2 & 1368 & 0.15 & 1240 & 0.16 \\
\hline
\end{tabular}

It can be seen that 8 of the 12 groups equal or exceed $1 \%$ of participants in the process and 4 do not reach the minimum established. It was necessary to continue with the program and calendar for the elaboration of the plan and take as reference the considerations of Vallejo and Hauselman [73] in which they establish that a participatory process is a compromise between speed and legitimacy, where speed will depend on the number of participants in the process. If the method does not allow progress in the process quickly, the participants will abandon it. In turn, as Figure 5 shows, there is an overlap among groups; some participants are, for example, owners, ranchers, comuneros, beekepers, 
etc. and it was considered that it was possible to guarantee the representativity of both groups and territories according to the definition considered.

\subsection{Adjustment of the Strategy}

The generic strategy was based on meetings held in each municipality; 466 posters were distributed in 425 population nucleuses, $43 \%$ of the total, to call for meetings. This informative phase was reinforced with the distribution of 1600 brochures placed at the most accessible points: health centers, administration offices. Attendance data for each meeting can be seen in Table 5 divided by municipality. On the whole, 453 people attended, which amounts to $2.37 \%$ of inhabitants in the area and $2.01 \%$ of the starting population.

Within a specific strategy, first, we held a meeting with the local administration where we informed them of the start of the forest plan and asked for their collaboration for the process. After that, we sent 329 letters with specific messages about the implications of the forest plan with acknowledgement of receipt to the leaders of stakeholders within the categories of property and users. The message and the means used to reach each stakeholder focused on the interests that each group has with respect to forest planning. Thus, for example, for the forest communities, the importance to the plan of the use of their forest was indicated; for the hunters, the implications of the plan for hunting species was indicated; and for environmental groups the importance of the plan for conservation was indicated.

\subsection{Intensification of Communication}

Analyzing the results of the previous stage, we noticed the low representation of two municipalities: As Nogais and Piedrafita do Cebreiro. Therefore, we decided to reinforce the diffusion strategy there by means of a new diffusion process and a call for a new informative meeting. The result is shown in Table 6.

With this new process, we substantially increased the total percentage of attendance in the municipality of As Nogais (2.57\%). However, in the case of Piedrafita do Cebreiro, attendance was still low $(1.10 \%)$, just above the established limit as the aim for territorial representation.

Table 6. Registration figures in the participative process by municipality.

\begin{tabular}{|c|c|c|c|c|c|}
\hline Municipality & $\begin{array}{c}\text { Number of } \\
\text { People Present }\end{array}$ & Registered & $\%$ Registration & $\begin{array}{c}\text { Initial } \\
\text { Population }\end{array}$ & $\begin{array}{c}\% \text { Initial } \\
\text { Population }\end{array}$ \\
\hline Baleira & 44 & 32 & 72.73 & 2230 & 1.43 \\
\hline Becerreá & 72 & 44 & 61.11 & 3406 & 1.29 \\
\hline Cervantes & 71 & 54 & 76.06 & 2837 & 1.90 \\
\hline A Fonsagrada & 107 & 72 & 67.29 & 6317 & 1.14 \\
\hline As Nogais & 40 & 31 & 77.5 & 1552 & 2.00 \\
\hline Pedrafita do Cebreiro & 13 & 13 & 100 & 1240 & 1.05 \\
\hline TOTAL & 479 & 303 & 63.26 & 22,526 & 1.32 \\
\hline
\end{tabular}

\subsection{Opening of the Process}

The process started on 22 December 2008 and finished on 28 August 2009. The web page www.planforestaldistritovii.com had 2271 visits, 9.16 visits/day, 1030 different users (5\% of the district's population), and an average duration of visit of $5^{\prime} 26^{\prime \prime}$.

After the diffusion stage finished, the registration process started. 303 people registered $(1.32 \%$ of the initial population). The end of the diffusion process concluded with the possibility of signing up in the participation process in the forest plan. This was for administrative requirements and the convenience of being in contact with people interested in continuing to participate. In Table 7, we can see the results organized by municipality (territorial level) and, in Table 8, organized by stakeholder (sectorial level). 
Regarding the age of the participants, this encompassed people aged from 22 to 82 , with more participants over 65 . Regarding their sex, over $94 \%$ were men. The misrepresentation of women can be explained by cultural factors, as happens in other places [14]. In relation to training, $24 \%$ of participants had a university degree, especially the younger ones, $23 \%$ completed sixth form, and $53 \%$ had basic training.

Table 7. Number of people registered in each interest group.

\begin{tabular}{|c|c|c|c|c|c|c|c|}
\hline Category & Stakeholders & Registered & $\%$ & $\begin{array}{c}\% \text { Initial } \\
\text { Population }\end{array}$ & Total & $\%$ Total & $\begin{array}{c}\% \text { Initial } \\
\text { Population }\end{array}$ \\
\hline \multirow{2}{*}{ Property } & Individual forest owners & 135 & 44.55 & 1.38 & \multirow[b]{2}{*}{216} & \multirow[b]{2}{*}{71.29} & \multirow[b]{2}{*}{1.16} \\
\hline & Collective forest owners & 81 & 26.73 & 0.92 & & & \\
\hline \multirow{2}{*}{ Regulator } & Local administration & 1 & 0.33 & 11.11 & \multirow{2}{*}{10} & \multirow{2}{*}{3.30} & \multirow{2}{*}{4.15} \\
\hline & Forest administration & 9 & 2.97 & 3.45 & & & \\
\hline \multirow{9}{*}{ Resource user } & Farmers and stockbreeders & 44 & 14.52 & 2.22 & \multirow{8}{*}{77} & \multirow{8}{*}{25.41} & \multirow{5}{*}{1.02} \\
\hline & Hunters & 8 & 2.64 & 0.59 & & & \\
\hline & Beekeeper & 1 & 0.33 & 0.23 & & & \\
\hline & Local forest company & 10 & 3.30 & 18.87 & & & \\
\hline & Other related companies & 1 & 0.33 & 0.91 & & & \\
\hline & Forest owners associations & 6 & 1.98 & 3.8 & & & \multirow{3}{*}{7.74} \\
\hline & Ecological groups & 3 & 0.99 & 1.9 & & & \\
\hline & Non-profit organizations & 4 & 1.32 & 100 & & & \\
\hline & TOTAL & 303 & 100 & - & 303 & 100 & - \\
\hline
\end{tabular}

\subsection{Results of the Cost and Effort of Diffusion}

The cost of the diffusion process was estimated by measuring the working hours of the technical staff as indicators, with a result of $289 \mathrm{~h}$. In Table 8, we can see the hours classified by stages. The most time-consuming stage is that of the generic strategy, with $135.42 \mathrm{~h}$ ( $47 \%$ of resources). The effort in the area of validation is $0.17 \mathrm{~h}$ of technical staff per square kilometer and $0.95 \mathrm{~h}$ per participant.

Table 8. Summary of diffusion cost by stage measured in technical staff working hours.

\begin{tabular}{ccc}
\hline Stage & Effort (h Technical Staff) & \% Effort \\
\hline Previous & 130 & 45.00 \\
Outline peparation & 40 & 13.84 \\
Outline meeting & 10 & 3.46 \\
Diffusion preparation & 80 & 27.69 \\
Specific strategy & 23.5 & 8.13 \\
Diffusion meeting & 6 & 2.08 \\
Initial meeting & 4 & 1.38 \\
Meeting with mayors & 4.5 & 1.56 \\
District meeting & 3 & 1.04 \\
Letters & 6 & 2.08 \\
Generic strategic & 135.42 & 46.87 \\
Information meetings & 13.07 & 4.52 \\
Putting up posters & 122.35 & 42.35 \\
Total & 288.92 & 100 \\
\hline
\end{tabular}

\section{Discussion}

As stated by Aasetre [13], the different interests in the resources to be the subject of planning must be key to defining the structure of participation, so that the sensibilities that influence resource management are included in the planning stage. In the proposed methodology, we identified three universal types of stakeholders: property, forest-resource users and regulators. Other authors establish different numbers: Kangas et al. [21] propose eight; Marques et al. [57] and Nordström et al. [27] propose four; whereas Agnoloni et al. [58] and Ferretti et al. [59] propose two. The structure of categories must be simple enough to be capable of extrapolation to a wide range of forest areas. 
They must also be homogeneous and internally coherent enough to be representative of the interests in resources of each group and to represent all the sensibilities and interests in the land together.

The validation of the methodology has classified 12 groups of stakeholders in the study area. These results coincide with those in Sheppard and Meitner [36], Primmer and Kyllönen [56], Hiltunen et al. [19], Agnoloni et al. [58], Marques et al. [57], and Kangas et al. [21]. This may be due to the repetition of a high number of stakeholders in different times and places. This common group is associated with the categories of property and regulator. The higher or lower number of new stakeholders is motivated by the complexity of the category of forest-resource users. This category depends on the historical component of use and the relative importance of forest activity as a socioeconomic activity, together with the level of definition of the classification methodology used by researchers.

Once the structure of participation has been developed, the next question is related to stakeholder representativity. Our methodological proposal takes into account the proposals by Janse and Konijnendijk [18] that considered that the number of participants was conditioned by factors related to participation tools and communication, always adapted to the place and time of the process. As pointed by Côté and Bouthillier [53], it is necessary to consider the dimension of the area and the time available for the process.

There is a high number of participants in the validation, $303,1.32 \%$ of the initial population, which contrasts with an average of 54 in similar works consulted (Table 1). The territorial distribution is considerably higher than the average of the referenced processes at 0.2 participants $/ \mathrm{km}^{2}$.

The results show that, using the validated methodology, we obtained six times more participants than the average with a similar number of stakeholders. Our effort in the diffusion stage has allowed us to obtain a level of representativity measurable in terms of stakeholders and territories. Gaining participants in the amount and distribution considered as objective was not achieved in the first stage, and it was necessary to resort to the stage of intensification of communication.

It is necessary to assess participant representativity $[39,47]$ and whether participants are evenly distributed $[9,27,39]$. Herein lies the importance that all interests groups are present and that their representation in the public participation process is proportional to its real representation in the initial population. The statistical validation guarantees the representativity of the process.

The next question answered is whether the diffusion process has been attractive enough. We considered the relationship between the number of people registered and the number of those who attended informative meetings. The global result is that $63.26 \%$ of participants in the meeting registered and participated in the process. Purdon [74] stated the need for more transparent participative processes so that they could be more attractive to the population. Leskinen [7] includes environmental aspects which will raise people's interest in participating in planning.

Deming [71] stated that one of the challenges of research in public participation is to achieve efficient methodologies. So far the works revised have not been concerned with this issue. However, the results obtained with the methodology we propose show that the cost or effort is relatively low, making it a highly efficient methodological process.

The methodology proposed for the case study can be replicated in other forest-planning processes taking into account the local characteristics in each area as key elements for the methodology's adaptation: to carry out a correct stakeholder analysis in the area, to establish a representation percentage, a strategy considering the role of each stakeholder, and to increase diffusion in those groups that do not reach the initial representation aim.

Currently, we do not have data about the cost of the diffusion stage of public participation processes in forest planning. Our methodology aims to offer an answer to this question.

A more intensive process could improve performance and innovation [21,51]. In some processes, participants find that too much time is devoted to participation [21], so it is necessary to find a balance between participants' time and the results aimed. Thus, it is necessary to use new technologies to decrease displacements and meeting times. 


\section{Conclusions}

Public participation processes within forest plans are currently being debated. Our work attempts to answer some of the uncertainties that have been formulated. After the implementation of the diffusion stage in the forest plan in the district of Fonsagrada-Os Ancares some answers that help to improve public participation can be provided for application to similar processes.

The diffusion stage has been proved to be an essential phase in the beginning of forest-resource planning processes. It has a high influence in stakeholder representativity that will, in turn, influence the rest of the processes, both regarding the quality of proposals and the actual forest management [75].

The literature reviewed, while highlighting the importance of diffusion in participatory processes, does not clearly establish indicators of appropriate levels. Our contribution focuses on proposing measurable objectives adapted to the characteristics of the area and a method to achieve them.

Diffusion processes are important because they provide the participative process with "raw material" and "fuel". The diffusion stage is a key element in the process because failure at this stage means failure of the overall process. The aim of this is to raise interest and ensure a sufficient number of stable participants for the process to fulfil the representativity criteria. In this case, $63 \%$ of those attending the information meetings participated in the whole process.

Once the aim of attracting the attention of a representative percentage of the population has been fulfilled, the challenge is to keep the attention of the highest possible number of participants throughout the process so that they provide information and knowledge right up to the conclusion of the plan.

The minimum number of participants is going to depend on the percentage fixed at the beginning of the process, which must be established considering both the territory and the sector. The validation of participant representativity will be determined by the fulfillment of the minimum percentage (at territorial and sectorial level) and the analysis of theoretical participant distribution in contrast to the actual distribution. In case the minimum percentage is not reached ( $1 \%$ of the initial population in our case), it is necessary to increase diffusion until it is reached. It is also necessary to apply statistical contrasts to verify that results have been achieved, in our case, the $\mathrm{T}$ test for dependent samples.

The cost of the process is a limiting factor for its generalization in an area. In this case, it has been considered in every stage and the optimization of financial resources has resulted in an economical process with a total cost of $5 € / \mathrm{km}^{2}$ or $25 € /$ participant.

When a process begins it is necessary to have real public participation and, in this sense, new technologies are very efficient at providing transparency, swiftness and equity in the process. In the case described in this work, the web page of the forest plan ensured the transparency of the process, allowing $5 \%$ of the population to follow it.

Author Contributions: Xabier Bruña-García carried out the case study. Manuel F. Marey-Pérez provided expertise in the methodology and analysis of the results. The article was improved by the contributions of all of the co-authors at various stages of the analysis and writing process.

Acknowledgments: We would like to extend our gratitude to all those people who actively contributed their participation in formulating the Forest Plan of the Fonsagrada-Os Ancares District. We want to thank the anonymous reviewers for their contributions.

Conflicts of Interest: The authors declare no conflict of interest.

\section{References}

1. Díaz-Balteiro, L.; Romero, C. Making forestry decisions with multiple criteria: A review and an assessment. For. Ecol. Manag. 2008, 174, 447-457. [CrossRef]

2. Zilberman, D.; Goetz, R.; Garrido, A. Natural Resource Management and Policy; Springer: Berlin/Heidelberg, Germany, 2010.

3. Food and Agriculture Organization (FAO). Principles of Sustainable Tropical Forest Management Where Wood Production Is the Primary Objective; Forest Resources-Forestry Department: Roma, Italy, 1998. 
4. Bruña-García, X.; Marey-Pérez, M.F. Public participation: A need of forest planning. iForest 2014, 7, $216-226$. [CrossRef]

5. Gerber, J. Beyond dualism-The social construction of nature and the natural and social construction of human beings. Progress Hum. Geogr. 1997, 21, 1-17. [CrossRef]

6. Pelkonen, P.; Pitkänen, A.; Schmidt, P.; Oesten, G.; Piussi, P.; Rojas, E. Forestry in Changing Societies in Europe; Silva Network, Part I and II; Silva Network, Part I and II, University of Joensuu:: Joensuu, Finland, 2000.

7. Leskinen, L.A. Purposes and challenges of public participation in regional and local forestry in Finland. For. Policy Econ. 2004, 6, 605-618. [CrossRef]

8. Grundmann, R. The role of expertise in governance processes. For. Policy Econ. 2009, 11, 398-403. [CrossRef]

9. Lakicevic, M.; Srdjevic, Z.; Srdejevic, B.; Zlatic, M. Decision making in urban forestry by using approval voting and multicriteria approval method (case study: Zvezdarska forest, Belgrade, Serbia). Urban For. Urban Green. 2014, 13, 114-120. [CrossRef]

10. Paletto, A.; Giacovelli, G.; Pastorella, F. Stakeholders' opinions and expectations for the forestbased sector: A regional case study in Italy. Int. For. Rev. 2017, 19, 68-78.

11. De Meo, I.; Ferretti, F.; Paletto, A.; Cantiani, M.G. An approach to public involvement in forest landscape planning in Italy: A case study and its evaluation. Ann. Silvicult. Res. 2017, 41, 54-66.

12. International Labour Office (ILO). Public Participation in Forestry in Europe and North America: Report of the Team of Specialists on Participation in Forestry; Report of the FAO/ECE/ILO Joint Committee Team of Specialists on Participation in Forestry; WP 163; International Labour Office: Geneva, Switzerland, 2000.

13. Aasetre, J. Perceptions of communication in Norwegian forest management. For. Policy Econ. 2006, 8, 81-92. [CrossRef]

14. Atmiş, E.; Özden, S.; Lise, W. Public participation in forestry in Turkey. Ecol. Econ. 2007, 62, 352-359. [CrossRef]

15. Hellström, E. Conflict Cultures-Qualitative Comparative Analysis of Environmental Conflicts in Forestry; Silva Fennica Monographs; University of Helsinki: Helsinki, Finland, 2001; Volume 2, p. 109.

16. Kangas, J.; Store, R. Internet and teledemocracy in participatory planning of natural resources management. Landsc. Urban Plan. 2003, 62, 89-101. [CrossRef]

17. Santos, R.; Antunes, P.; Baptista, G.; Mateus, P.; Madruga, L. Stakeholder participation in the design of environmental policy mixes. Ecol. Econ. 2006, 60, 100-110. [CrossRef]

18. Janse, G.; Konijnendijk, C. Communication between science, policy and citizens in public participation in urban forestry-Experiences from the Neighbourwoods project. Urban For. Urban Green. 2007, 6, $23-40$. [CrossRef]

19. Hiltunen, V.; Kurttila, M.; Leskinen, P.; Pasanen, K.; Pykäläinen, J. Mesta: An internetbased decision-support application for participatory strategic-level natural resources planning. For. Policy Econ. 2009, 11, 1-9. [CrossRef]

20. Elsasser, P. Rules for participation and negotiation and their possible influence on the content of a national forest program. For. Policy Econ. 2002, 4, 291-300. [CrossRef]

21. Kangas, A.; Saarinen, N.; Saarikoski, H.; Leskinen, L.A.; Hujala, T.; Tikkanen, J. Stakeholder perspectives about proper participation for Regional Forest Programmes in Finland. For. Policy Econ. 2010, 12, $213-222$. [CrossRef]

22. Lennox, J.; Proctor, W.; Russell, S. Structuring stakeholder participation in New Zealand's water resource governance. Ecol. Econ. 2011, 70, 1381-1394. [CrossRef]

23. Jansson, M.; Gunnarsson, A.; Martensson, F.; Andersson, S. Children's perspectives on vegetation establishment: Implications for school ground greening. Urban For. Urban Green. 2014, 13, 166-174. [CrossRef]

24. Germain, R.H.; Floyd, D.W.; Stehman, S.V. Public perceptions of the USDA Forest Service public participation process. For. Policy Econ. 2001, 3, 113-124. [CrossRef]

25. Higgs, G.; Berry, R.; Kidner, D.; Langford, M. Using IT approaches to promote public participation in renewable energy planning: Prospects and challenges. Land Use Policy 2008, 25, 596-607. [CrossRef]

26. Garmendia, E.; Stagl, S. Public participation for sustainability and social learning: Concepts and lessons from three case studies in Europe. Ecol. Econ. 2010, 69, 1712-1722. [CrossRef]

27. Nordström, E.M.; Eriksson, L.O.; Öhman, K. Integrating multiple criteria decision analysis in participatory forest planning: Experience from a case study in northern Sweden. For. Policy Econ. 2010, 12, 562-574. 
28. Buchy, M.; Hoverman, S. Understanding public participation in forest planning: A review. For. Policy Econ. 2000, 1, 15-25. [CrossRef]

29. Hwang, C.L.; Yoon, K. Multiple Attribute Decision Making. Methods and Applications: A State of the Art Survey; Springer: Berlin, Germany, 1981.

30. Pykäläinen, J.; Kangas, J.; Loikkanen, T. Interactive decision analysis in participatory strategic forest planning: Experiences from state owned Boreal forests. J. For. Econ. 1999, 5, 341-364.

31. Kangas, A.; Kangas, J.; Pykäläinen, J. Outranking methods as tools in strategic natural resources planning. Silva Fennica 2001, 35, 215-227. [CrossRef]

32. Ananda, J.; Herath, G. Incorporating stakeholder values into regional forest planning: A value function approach. Ecol. Econ. 2003, 45, 75-90. [CrossRef]

33. Ananda, J.; Herath, G. The use of Analytic Hierarchy Process to incorporate stakeholder preferences into regional forest planning. For. Policy Econ. 2003, 5, 13-26. [CrossRef]

34. Maness, T.C.; Farrell, R. A multi-objective scenario evaluation model for sustainable forest management using criteria and indicators. Can. J. For. Res. 2004, 34, 10-14. [CrossRef]

35. Laukkanen, S.; Palander, T.; Kangas, J. Applying voting theory in participatory decision support for sustainable timber harvesting. Can. J. For. Res. 2004, 34, 1511-1524. [CrossRef]

36. Sheppard, S.R.J.; Meitner, M. Using multi-criteria analysis and visualisation for sustainable forest management planning with stakeholder groups. For. Ecol. Manag. 2005, 207, 171-187. [CrossRef]

37. Hiltunen, V.; Kangas, J.; Pykäläinen, J. Voting methods in strategic forest planning—Experiences from Metsähallitus. For. Policy Econ. 2008, 10, 117-127. [CrossRef]

38. Ananda, J.; Herath, G. A critical review of multi-criteria decision making methods with special reference to forest management and planning. Ecol. Econ. 2011, 68, 2535-2548. [CrossRef]

39. Elsasser, P. Do "stakeholders" represent citizen interests? An empirical inquiry into assessments of policy aims in the National Forest Programme for Germany. For. Policy Econ. 2007, 9, 1018-1030. [CrossRef]

40. Mayer, P. The MCPFE and COST E19. In NFP Research: Its Retrospect and Outlook; Glück, P., Voitleithner, J., Eds.; Institute of Forest Sector Policy and Economics: Wien, Austria, 2004; pp. 183-194.

41. Barstad, J. A Planner's View on National Forest Programmes. In NFP Research: Its Retrospect and Outlook; Glück, P., Voitleithner, J., Eds.; Institute of Forest Sector Policy and Economics: Wien, Austria, 2004; pp. 65-82.

42. Grimble, R.; Wellard, K. Stakeholder methodologies in natural resource management: A review of principles, contexts, experiences and opportunities. Agric. Syst. 1997, 55, 173-193. [CrossRef]

43. Banville, C.; Landry, M.; Martel, J.M.; Boulaire, C. A stakeholder approach to MCDA. Syst. Res. Behav. Sci. 1998, 15, 15-32. [CrossRef]

44. Gong, Y.; Bull, G.; Baylis, K. Participation in the world's first clean development mechanism forest project: The role of property rights, social capital and contractual rules. Ecol. Econ. 2010, 69, 1292-1302. [CrossRef]

45. Tikkanen, J.; Leskinen, L.A.; Leskinen, P. Forestry organisation network in Northern Finland. Scand. J. For. Res. 2003, 18, 547-599. [CrossRef]

46. Paletto, A.; Hamunen, K.; De Meo, I. Social network analysis to support stakeholder analysis in participatory forest planning. Soc. Nat. Res. 2015, 28, 1108-1125. [CrossRef]

47. O'Neill, J. Representing people, representing nature, representing the world. Environ. Plan. C Gov. Policy 2001, 19, 483-500. [CrossRef]

48. McColl, S.F.; Guthrie, K. Mapping the dimensións of succesful public participation in messy natural resources management situations. Soc. Nat. Res. 2001, 14, 309-323.

49. Martins, H.; Borges, J.G. Addressing collaborative planning methods and tools in forest management. For. Ecol. Manag. 2007, 248, 107-118. [CrossRef]

50. FAO. Elaboración de una Política Forestal Eficaz-Una Guía; Development of an Effective Forest Policy-A Guide; FAO: Roma, Italy, 2010.

51. Beierle, T.C.; Cayford, J. Democracy in Practice: Public Participation in Environmental Decisions; Resources for the Future: Washington, DC, USA, 2002.

52. Kangas, J.; Kangas, A. Multiple criteria decision support in forest management-The approach, methods applied, and experiences gained. For. Ecol. Manag. 2005, 207, 133-143. [CrossRef]

53. Côté, M.; Bouthillier, L. Assesssing the effect of public involvement processes in forest management in Quebec. For. Policy Econ. 2002, 4, 213-225. [CrossRef] 
54. Tress, B.; Tress, G. Scenario visualisation for participatory lLandscape planning-A study from Denmark. Landsc. Urban Plan. 2003, 64, 161-178. [CrossRef]

55. Sipilä, M.; Tyrväinen, L. Evaluation of collaborative urban forest planning in Helsinki, Finland. Urban For. Urban Green. 2005, 4, 1-12. [CrossRef]

56. Primmer, E.; Kyllönen, S. Goals for public participation implied by sustainable development, and the preparatory process of the Finnish National Forest Programme. For. Policy Econ. 2006, 8, 838-853. [CrossRef]

57. Marques, A.F.; Borges, J.G.; Lucas, B.; Garcia, J.; Melo, I. A participatory approach to design a toolbox to support forest management planning at regional level. For. Syst. 2013, 22, 340-358. [CrossRef]

58. Agnoloni, S.; Bianchi, M.; Bianchetto, E.; Cantiani, P.; De Meo, I.; Dibari, C.; Ferretti, F. I piani forestali territoriali di indirizzo: Una proposta metodologica. (The regional forest plans to address: A methodological proposal). Forest 2009, 6, 140-147. [CrossRef]

59. Ferretti, F.; Dibari, C.; De Meo, I.; Cantiani, P.; Bianchi, M. ProgettoBosco, a Data-Driven Decision Support System for forest planning. Math. Comput. For. Nat.-Resource Sci. 2011, 3, 27-35.

60. Marey-Pérez, M.F.; Rodríguez-Vicente, V. Forest transition in Northern Spain: Local responses on large-scale programmes of field-afforestation. Land Use Policy 2008, 26, 139-156. [CrossRef]

61. Rodríguez-Vicente, V.; Marey-Pérez, M. Assessing the role of the family unit in individual private forestry in northern Spain. Scand. J. For. Res. 2008, 23, 53-77. [CrossRef]

62. Rodríguez-Vicente, V.; Marey-Pérez, M. Analysis of individual private forestry in northern Spain according to economic factors related to management. J. For. Econ. 2010, 16, 269-295. [CrossRef]

63. Álvarez-López, C.J.; Riveiro-Valiño, J.A.; Marey-Pérez, M.F. Typology, classification and characterization of farms for agricultural production planning. Span. J. Agric. Res. 2008, 6, 125-136. [CrossRef]

64. Riveiro-Valiño, J.A.; Marey-Pérez, M.F.; Marco-Gutiérrez, J.L.; Álvarez-López, C.J. Procedure for the classification and characterization of farms for agricultural production planning: Application in the Northwest of Spain. Comput. Electron. Agric. 2008, 61, 169-178. [CrossRef]

65. Riveiro-Valiño, J.A.; Álvarez-López, C.J.; Marey-Pérez, M.F. The use of discriminant analysis to validate a methodology for classifying farms based on a combinatorial algorithm. Comput. Electron. Agric. 2009, 66, 113-120. [CrossRef]

66. Díaz-Varela, E.R.; Marey-Pérez, M.F.; Rigueiro-Rodríguez, A.; Álvarez-Álvarez, P. Landscape metrics for characterization of forest landscapes in a sustainable management framework: Potential application and prevention of misuse. Ann. For. Sci. 2009, 66, 301-311. [CrossRef]

67. Marey-Pérez, M.F.; Rodríguez-Vicente, V.; Álvarez-López, C.J. Practical application of multivariant analysis techniques to the forest management of active farmers in the northwest of Spain. Small Scale For. 2012, 11, 453-476. [CrossRef]

68. Marey-Pérez, M.F.; Gómez-Vázquez, I.; Díaz-Varela, E.R. Different approaches to the social vision of communal land management: The case of Galicia (Spain). Span. J. Agric. Res. 2010, 8, 848-863. [CrossRef]

69. Xunta de Galicia. Consellería de Medio Ambiente e Desenvolvemento Sostible. Plan de Ordenación de Recursos Naturais do Parque Natural de Os Ancares; Xunta de Galicia. Consellería de Medio Ambiente e Desenvolvemento Sostible: Santiago de Compostela, Spain, 2008.

70. OCDE. Creating Rural Indicators for Shaping Territorial Policy; OCDE: París, France, 1994.

71. Deming, W.E. Out of the Crisis; MIT Press: Cambridge, MA, USA, 1986.

72. Stenseke, M. Local participation in cultural landscape maintenance: Lessons from Sweden. Land Use Policy 2009, 26, 214-223. [CrossRef]

73. Vallejo, N.; Hauselmann, P. Gobernance and Multistakeholder Processes; UNCTAD/IISD: Winnipeg, MB, Canada, 2004.

74. Purdon, M. The Nature of ecosystem management: Postmodernism and plurality in the sustainable management of the boreal forest. Environ. Sci. Policy 2003, 6, 377-388. [CrossRef]

75. Bruña-García, X.; Marey-Pérez, M.F. Participative Forest Planning: How to obtain knowledge. For. Syst. 2018, 27. [CrossRef]

(C) 2018 by the authors. Licensee MDPI, Basel, Switzerland. This article is an open access article distributed under the terms and conditions of the Creative Commons Attribution (CC BY) license (http:/ / creativecommons.org/licenses/by/4.0/). 